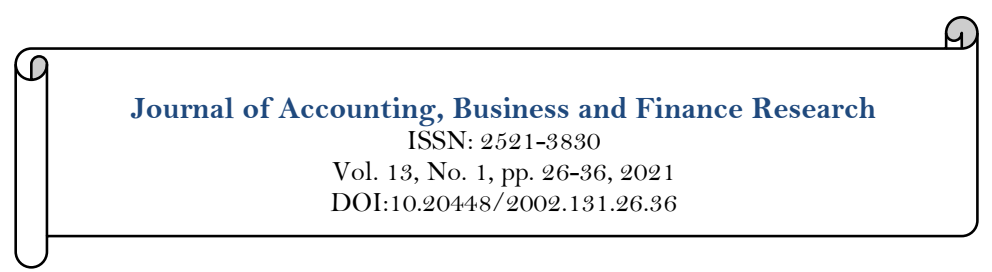

\title{
A Socioeconomic Study of Climate Change and its Impact on the Livelihoods of People Living Around the Coastal Areas of the Gambia
}

\section{Momodou Mustapha Fanneh}

School of Business and Public Administration, Department of Economics, University of the Gambia, The Gambia. Email:mmfanneh@utg.edu.gm

\begin{abstract}
The research aims to assess the effects of climate change on the livelihoods of people living around the coastal areas and the coping strategies used. The study uses a quantitative method with a semistructured interview questionnaire and convenient sampling method and conducts a survey of coastal community residents in Banjul, Barra, Bakau, Tanji, Sanyang, Gunjur, and Kartong using a descriptive analysis. The majority of respondents are self-employed as fishermen, fish dryers, fish smokers, ship builders and boat riders. Most of the borrowing is done individually, the line of credit is mostly below D20,000, and more than $85 \%$ receive less than that amount. More than $60 \%$ of the respondents have no access to land, and $4.71 \%$ stated that they do not have access to water. Most of the respondents rank their friends as their source of borrowing followed by families and banks. About 93\% stated that it takes them less than 40 minutes to get to the nearest health facility. Adaptation strategies employed to deal with health problems during variable and extreme climate are going to hospital, cleanliness, eating healthily, and using herbal medicine. More than $85 \%$ of the respondents did not experience a shortage of food in the period of a year, but the price of food has been increasing over the last five years. Finally, the respondents' preferred adaptation strategy is saving followed by getting involved in other livelihood activities, government assistance, cleaning the environment, tree planting, and protection of coastal areas.
\end{abstract}

\author{
Keywords: \\ Climate change \\ Socioeconomic \\ Livelihood \\ Coastal areas \\ Social networks \\ Coping strategies \\ JEL Classification: \\ A10, B55, C83, O10, Q50, Q54 \\ Licensed: \\ This work is licensed under a \\ Creative Commons Attribution 4.0 \\ License. \\ Publisher: \\ Scientific Publishing Institute \\ Received: 7 June 2021 \\ Revised: 25 August 2021 \\ Accepted: 10 September 2021 \\ Published: 20 October 2021
}

Funding: This study received no specific financial support.

Competing Interests: The authors declare that they have no competing interests

\section{Introduction}

The Gambia is a small country on the Western Coast of Africa within the latitude of $13^{\circ}$ to $15^{\circ}$ north of the equator. It is a narrow strip of land divided into North and South banks by the River Gambia, which extends inland for more than 400 kilometers on both banks of the river with varying widths ranging from 24 to 28 kilometers away from the borders with Senegal, covering an approximate land area of about 11,000 square kilometers. It is bordered on the North, South and East by the Republic of Senegal and on the West by the Atlantic Ocean. The country has a population of 2.101 million (World Bank, 2007)1. With 176 people per sq. $\mathrm{km}$, it is one of the most densely populated countries in Africa. Most of the population (57\%) is

${ }^{1}$ The Gambia Overview: Development news, research, data | World Bank 
concentrated around urban and peri-urban centers. The Gambian economy is small and hence relies primarily on tourism, agriculture and remittances, which are vulnerable to external shocks.

The Gambia has $80 \mathrm{kms}$ of open Atlantic coast from Buniada Point in the north to the mouth of the River Allahein in the south. Banjul is recognized as the most vulnerable city to sea level rises, followed by Barra and Bakau. In fact, the whole coastline is sensitive, with sandy shores and clayed cliffs. Most of the government infrastructures, businesses, tourism facilities and high value private properties are found within the coastal area. The Gambia is particularly vulnerable to climate change threats, including the rise in sea level, coastal erosion, increasing saline intrusion and flooding.

Climate change refers to a change in the state of the climate that can be identified by changes in the mean and or the variability of its properties and that persists for an extended period, typically decades or longer (IPCC, 2007). Climate change affects the livelihoods of coastal communities and will have a direct impact on the development of climate-dependent activities (such as infrastructure and agriculture) and indirect consequences for social systems (such as issues of poverty, conflict, health and education). As a result, climate change has the potential to undermine, and even undo, socioeconomic development in East Africa (Orindi \& Murray, 2005). Gambia's coastal zone is inhabited by 14 communities with a total population of 172,000, according to the 2013 census. Banjul, the capital city of the Republic, is the most populous settlement, followed by Bakau. The four settlements (Banjul, Bakau, Brufut and Gunjur) account for 59\% of the total coastal population. Coastal communities are urbanized and more than $90 \%$ are in urban residences. Most of the fishing, trading, tourism, services, and secondary sector activities of the Gambia are found within one kilometer of the shoreline. This research answers the following questions: What are the socioeconomic characteristics of coastal residents? What is local communities' knowledge of climate change effects and processes? How does it affect their livelihoods? How do they cope with the effects? What are their adaptive solutions? The objective of the study is to assess the effects of climate change on the livelihoods of people living around the coastal areas and assess adaptation strategies.

Some constraints that may be considered when assessing community resilience to climate change threats include people's level of education and skills, the range of employment and income sources, access to productive lands and resources, and the availability of public services and credit facilities, among others.

\section{Literature Review}

Several studies have been carried out to examine households' perceptions of climate change (Acquah, 2011; Aphunu \& Nwabeze, 2012; Ayanwuyi, Kuponiyi, Ogunlade, \& Oyetoro, 2010; Combest-Friedman, Christie, \& Miles, 2012; Devkota, Bajracharya, Maraseni, Cockfield, \& Upadhyay, 2011; Haque, Yamamoto, Malik, \& Sauerborn, 2012; Tambo \& Abdoulaye, 2013). These studies are useful in understanding different approaches that may be used to assess households' perceptions to climate change in local communities as well as the determinants thereof. A central methodological approach was used by these studies to obtain primary data on several variables, such as the socioeconomic characteristics of households in the study area (age, gender, educational level, marital status, ethnicity, household income, etc.), perceptions of change in climatic variables (rainfall, temperature, storm frequency, etc.), and other indicators of exposure to climate change (health, floods, crop yield, etc.) using questionnaires, structured interviews, or focused group discussions. The perceptions of households are then assessed using the descriptive statistics of the variables obtained.

The impacts of climate change can be broadly grouped into three categories - ecological, social, and economic. The ecological impacts of climate change include shifts of vegetation types and associated impacts on biodiversity (Elliott \& Baker, 2004), change in forest density and agricultural production (Adams et al., 1990; Smith, Martino, \& Cai, 2007), expansion of arid land (Karl, Melillo, \& Peterson, 2009), decline in water quantity and quality (Milly, Betancourt, \& Falkenmark, 2008), effects on aquatic species and ecosystems (U.S. Environmental Protection Agency (EPA), 2008), and stresses from pests, diseases and wildfire (Alig, Adams, Joyce, \& Sohngen, 2004; Gan, 2004). Social impacts may include changes in equity, risk distribution, human health impacts, and the relocation of populations (Karl et al., 2009). Economic impacts include increased risk and uncertainty of forest and agricultural production (Smith et al., 2007), alteration in productivity for crops and forest products (Feng \& Hu, 2007), changes in the supply of ecosystem goods and services (Sohngen \& Sedjo, 2005), and altered costs of utilities and services (Scott \& Huang, 2007).

\section{Methodology}

The methodology used in the study is quantitative in nature and uses a descriptive analysis. To conduct this study, a semi-structured interview questionnaire was used to obtain quantitative data from people in villages in coastal communities. The survey involved the design and administration of questionnaires through personal interviews on randomly selected men and women in each of the coastal communities selected for the study. The selection of individuals to be surveyed was based on the convenience sampling method. Surveys were administered in Banjul, Barra, Bakau, Tanji, Sanyang, Gunjur, and Kartong to gather information on individual characteristics, livelihood strategies, social networks, sensitivity to health, sensitivity to food, sensitivity to water, sensitivity to exposure, and adaptation scenarios. A total of 297 questionnaires were administered to fishermen, fish dryers, fish smokers, shop owners, drivers, boat builders, farmers, hotel 
workers, and others. The target sample size was 300 individuals whose livelihoods depend on the coastal activities and who face the possible threats of climate change. The response rate was $99 \%$.

\section{Analysis and Discussion of Results}

The results from the study using the individual survey questionnaire are summarized here. The survey highlighted the livelihood activities in the coastal areas; the socioeconomic characteristics of the respondents; their livelihood strategies; access to health, food, water, finance and communication assets; social networks; and sensitivities of people to food, water, and health care as a result of climate change.

\subsection{Socioeconomic Characteristics of Respondents}

The socioeconomic characteristics of respondents are provided in Table 1. In all the coastal communities surveyed, $68.35 \%$ of the respondents are household heads and $24.15 \%$ are female. Most of them are married $(75.59 \%)$ and $74.74 \%$ said they are educated. In terms of age, the respondents aged $30-39$ constitute the largest group, followed by those aged 40-49.

\begin{tabular}{|c|c|c|}
\hline Variable & Frequency & Percentage \\
\hline \multicolumn{3}{|l|}{ Household head } \\
\hline Yes & 203 & 68.35 \\
\hline $\mathrm{No}$ & 94 & 31.65 \\
\hline \multicolumn{3}{|l|}{ Gender } \\
\hline Female & 71 & 24.15 \\
\hline Male & 223 & 75.85 \\
\hline \multicolumn{3}{|l|}{ Marital status } \\
\hline Divorced & 3 & 1.02 \\
\hline Married & 223 & 75.59 \\
\hline Single & 65 & 22.03 \\
\hline Widowed & 4 & 1.36 \\
\hline \multicolumn{3}{|l|}{ Education } \\
\hline Yes & 219 & 74.74 \\
\hline No & 70 & 23.89 \\
\hline Other & 4 & 1.37 \\
\hline \multicolumn{3}{|l|}{ Age } \\
\hline 10 to 19 & 7 & 2.44 \\
\hline 20 to 29 & 56 & 19.51 \\
\hline 30 to 39 & 104 & 36.24 \\
\hline 40 to 49 & 61 & 21.25 \\
\hline 50 to 59 & 41 & 14.29 \\
\hline 60 to 69 & 13 & 4.53 \\
\hline 70 to 79 & 2 & 0.70 \\
\hline 80 to 89 & 3 & 1.05 \\
\hline
\end{tabular}

The level of education of respondents is important in dealing with climate change issues. Of the respondents who are educated $97.31 \%$ reached the levels of pre-school, primary, secondary, adult-literacy or no formal and informal education (see Figure 1). All women interviewed are educated at the primary, secondary, and adult-literacy levels. Regarding ethnicity, most of the respondents are Serer (27.95\%), followed by Wolof (20.54\%) and Mandinka (20.20\%).

\subsection{Respondents' Income, Employment Type and Primary Source of Income}

The survey addresses the respondents' primary source of income, employment status, and annual income from the main occupation. The annual incomes of all respondents are provided in Table 2. From all the areas surveyed, $44.67 \%$ of the respondents stated that their annual income is between 0 to less than 10,000 Dalasis per year, $83.51 \%$ earn less than 40,000 Dalasi per year, and $16.49 \%$ of the respondents earn above 40,000 Dalasis per year. Most women earn below D20,000 per annum (58\%), and $8.33 \%$ of women earn above D40,000. Poverty is very high among women in the coastal areas.

The results of the study, as shown in Figure 2 and Table 3, reveal that of the respondents surveyed, about $80.34 \%$ are self-employed as fishermen, fish dryers, fish smokers, ship builders and boat riders. Only $1.36 \%$ are not working, and $87.67 \%$ of women whose livelihoods depend on the coastal areas are self-employed. The primary sources of income for most women in the coastal areas are fishing, fish drying and fish smoking $(45.71 \%)$, followed by trading $(32.86 \%)$. 


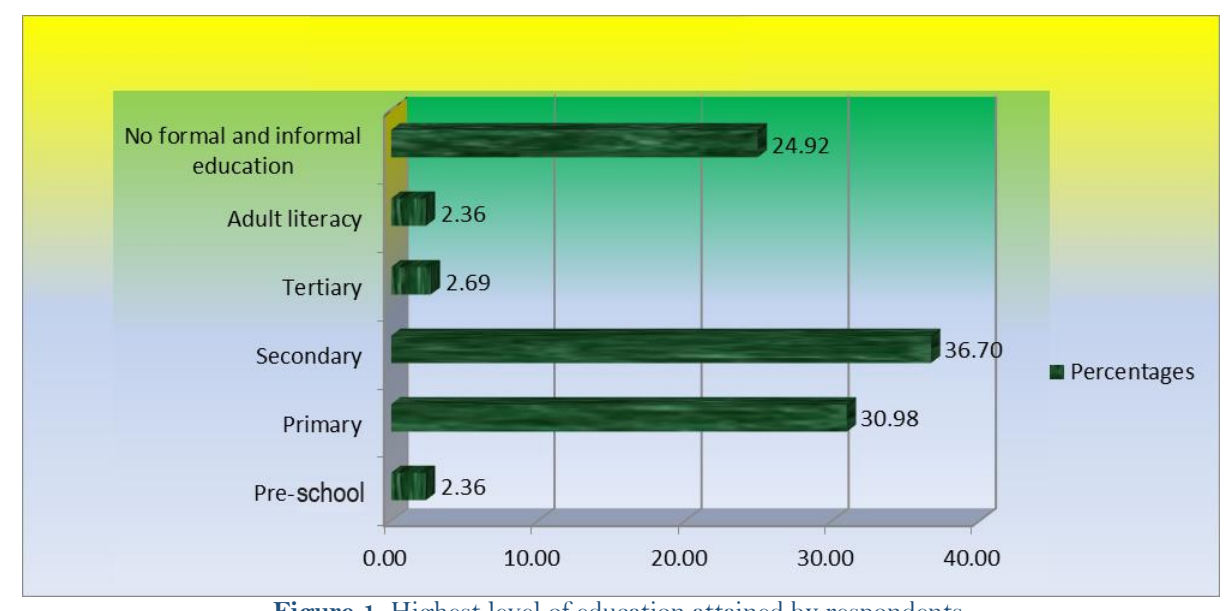

Figure 1. Highest level of education attained by respondents.

Table 2. Annual income of respondents (all communities).

\begin{tabular}{l|c|c}
\hline Annual income & Frequency & Percentage \\
\hline o to less than 10,000 & 130 & 44.67 \\
\hline 10,000 to less than 20,000 & 73 & 25.09 \\
\hline 20,000 to less than 30,000 & 30 & 10.31 \\
\hline 30,000 to less than 40,000 & 10 & 3.44 \\
\hline Above 40,000 & 48 & 16.49 \\
\hline Total & 291 & \\
\hline
\end{tabular}

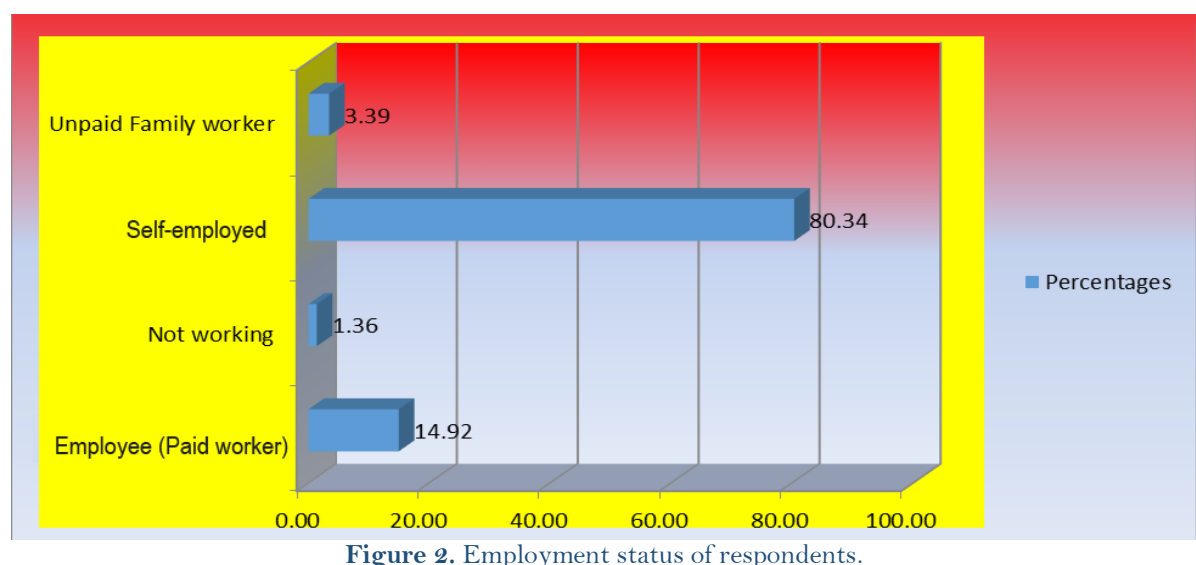

Of those who are self-employed, $45.06 \%$ earn between o to less than 10,000 Dalasis per annum, $70.81 \%$ earn below 20,000 Dalasis, and only $15.88 \%$ of the self-employed earn above 40,000 per annum. Women who are self-employed (62.90\%) earn between o to less than 10,000 Dalasis per annum, $79.83 \%$ earn below 20,000 Dalasis, and only $6.45 \%$ earn above 40,000 per annum. This shows that the percentage of self-employed women who earn below D10,000 per year is much greater than that of men. Similarly, those who earn below D20,000 is greater among women than men. Overall, the income levels along the coastal areas are low and are very much limited to activities along the coastline.

Table 3. Primary source of income.

\begin{tabular}{l|c|c|c}
\multicolumn{4}{c}{ Table 3. Primary source of income. } \\
\hline Primary source of income & Freq. & Percent & Cum. \\
\hline Batik & 6 & 2.16 & 2.16 \\
\hline Boat building and boat riding & 25 & 8.99 & 11.15 \\
\hline Driving & 4 & 1.44 & 12.59 \\
\hline Farming & 6 & 2.16 & 14.75 \\
\hline Fishing, fish drying and fish smoking & 153 & 55.04 & 69.78 \\
\hline Formal employment & 20 & 7.19 & 76.98 \\
\hline Hotel employee & 8 & 2.88 & 79.86 \\
\hline Tie dying or soap making & 2 & 0.72 & 80.58 \\
\hline Trading & 39 & 14.03 & 94.60 \\
\hline Others & 15 & 5.40 & 100.00 \\
\hline Total & 278 & 100.00 & \\
\hline
\end{tabular}


The main sources of income in the coastal areas are fishing, fish drying and fish smoking, with over half $(55.04 \%)$ of the respondents engaged in these activities. Boat building and boat riding constitute $8.99 \%$.

\subsection{Livelihood Strategies of Respondents}

The livelihood strategies of respondents and their relationship with climate change threats are discussed below. Climate change can affect migration trends (both internal and international migration) and access to communication assets, finance, resources, food, safe drinking water, and health facilities. Table 4 below shows the inter- and intra-zone movement of the respondents. During the last 12 months, $19.19 \%$ of the respondents lived and worked in a different zone. Most of the respondents stayed in their own zone. Therefore, there is less inter-zone labor mobility and more intra-zone labor mobility. Since there is a lot of competition in the livelihood activities around the coastal areas, there is no incentive to move to the other zones. Also, during the last 12 months, $14.81 \%$ of the respondents lived and worked in another country.

Table 4. Living/working in a different zone or in a different country.

\begin{tabular}{|c|c|c|c|c|}
\hline & & \multicolumn{3}{|c|}{$\begin{array}{c}\text { Lived and worked in another country in the last } 12 \\
\text { months }\end{array}$} \\
\hline & & No & Yes & Total \\
\hline \multirow{9}{*}{$\begin{array}{l}\text { Lived and worked in another zone in } \\
\text { the last } 12 \text { months }\end{array}$} & \multirow[t]{3}{*}{ No } & 234 & 6 & 240 \\
\hline & & 97.50 & 2.50 & 100 \\
\hline & & 92.49 & 13.64 & 80.81 \\
\hline & \multirow[t]{3}{*}{ Yes } & 19 & 38 & 57 \\
\hline & & 33.33 & 66.67 & 100.00 \\
\hline & & 7.51 & 86.36 & 19.19 \\
\hline & \multirow[t]{3}{*}{ Total } & 253 & 44 & 297 \\
\hline & & 85.19 & 14.81 & 100.00 \\
\hline & & 100.00 & 100.00 & 100.0 \\
\hline
\end{tabular}

\subsection{Access to Resources and Climate Change}

\subsubsection{Communication Assets}

Communication assets are important in business transactions and during variable and extreme climate conditions. Figure 3 shows the communication assets of respondents; $88.55 \%$ have access to mobile phones, $63.3 \%$ have access to radio, and $46.8 \%$ have access to TV. Regarding mobile service provider, the majority (70.71\%) use Africell, 17.85\% use Qcell, 14.82\% use Gamcel, and 11.11\% use Comium. Some of the respondents use more than one service provider.

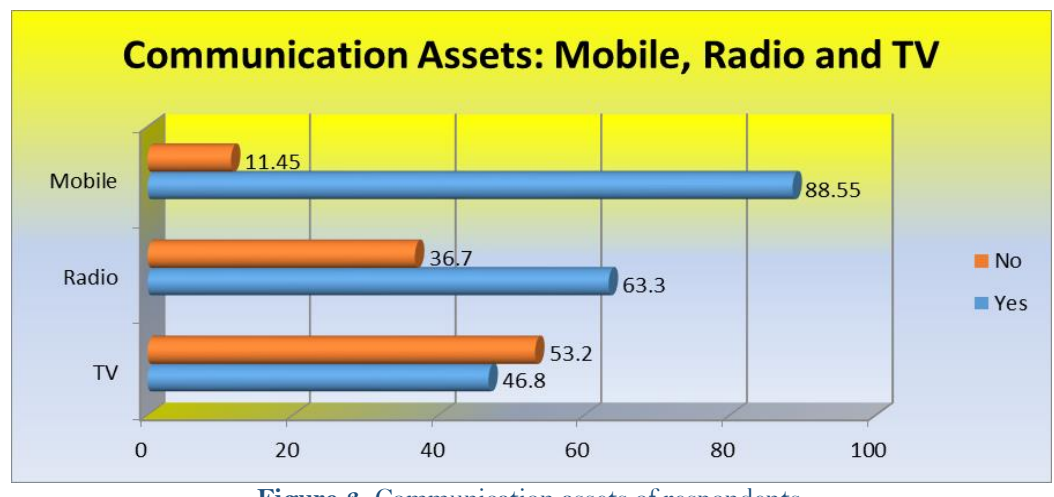

Figure 3. Communication assets of respondents.

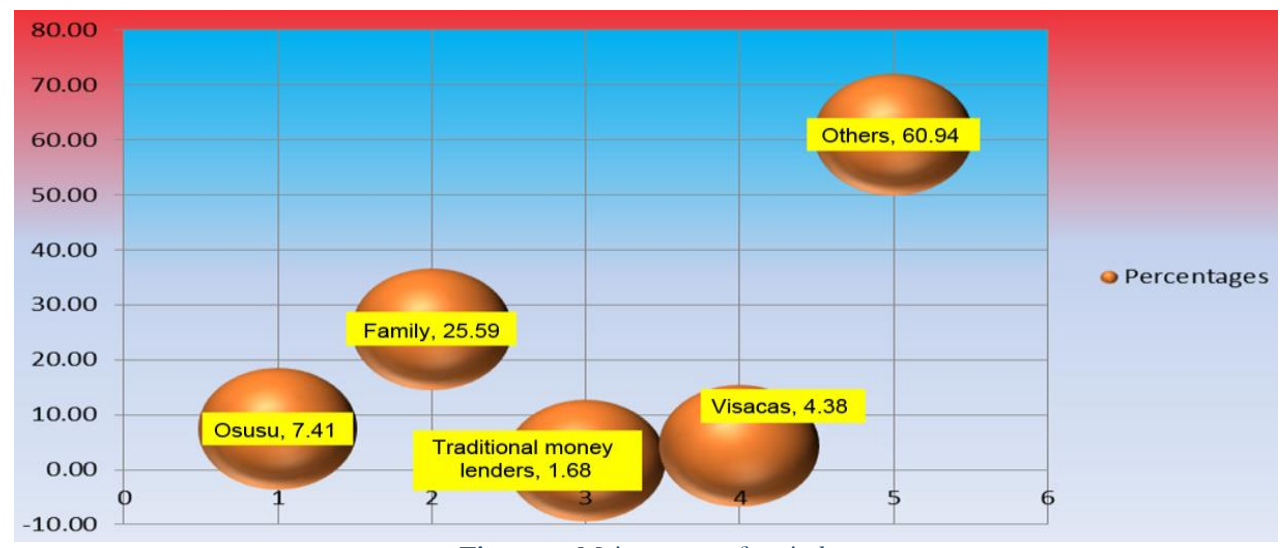

Figure 4. Main source of capital. 


\subsection{Access to Capital}

The main source of capital for people whose livelihood depend on coastal areas is other sources, followed by family and osusu (microfinancial capital accumulation) (see Figure 4). Other sources, which account for $60.94 \%$, include income from fishing, associations, friends, salary, pension and credit unions. Traditional money lending and VISACAs (Village Savings and Credit Associations) are at the bottom. Respondents tend to shy away from traditional money lending and VISACAs due to the terms of the loan and high interest rates attached.

\subsection{Access to Microfinance Institutions (MFIs)}

Access to financial resources is important for businesses in the coastal areas, and the distance to the nearest MFI is important to the respondents (see Table 5). Respondents with MFIs in their zones (67.86\%) travel less than 20 minutes to get to the nearest facility, $98.81 \%$ travel less than one hour to access the nearest microfinance facility, $74.74 \%$ get there by walking and the rest travel by bicycle or car. Most of the borrowing is done individually, with $76.32 \%$ of the respondents getting credit as individuals, and group borrowing makes up $10.53 \%$. The line of credit most of the time is below D20,000, and $85.34 \%$ of the time they receive less than that amount.

Table 5. Access to MFIs.

\begin{tabular}{l|c|c|c}
\hline Travel time & Freq. & Percent & Cum. \\
\hline O to less than 20 minutes & 57 & 67.86 & 67.86 \\
\hline 20 to less than 40 minutes & 19 & 22.62 & 90.48 \\
\hline 40 to less than 1 hour & 7 & 8.33 & 98.81 \\
\hline Above 1 hour & 1 & 1.19 & 100.00 \\
\hline Total & 84 & 100.00 & \\
\hline
\end{tabular}

\subsection{Access to Safe Drinking Water and Land}

The study also considered access to safe drinking water and land as important factors affecting respondents in relation to climate change issues. Figure 5 shows that $60.14 \%$ of the respondents have no access to land, and $4.71 \%$ stated that they do not have access to water. Of the women surveyed, $67.15 \%$ stated that they do not have the right to land ownership. Land tenure issues are a general problem in the country, and women lack both access to, and ownership of, land.

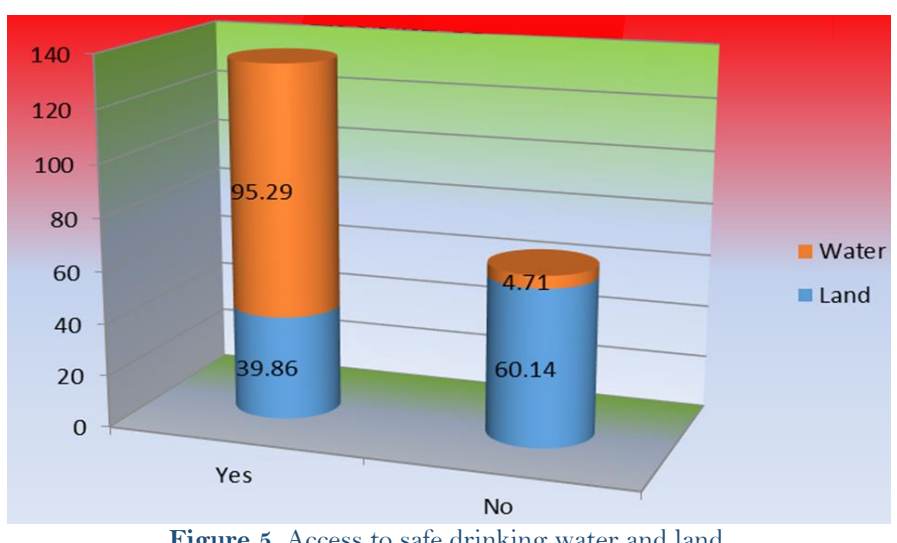

Figure 5. Access to safe drinking water and land.

\subsection{Social Networks and Climate Change}

Climate change affects the livelihoods of people and businesses along the coastal areas. Respondents receive and/or provide help in terms of cash, input, borrowing/lending money, communication, and training. Figure 6 provides a comparison of help given and received over the past month, with $47.93 \%$ of respondents giving help in terms of cash, while $22.76 \%$ received cash; $17.24 \%$ gave help in terms of input, while $7.59 \%$ received help in terms of input. In terms of borrowing money, $1 \%$ gave help, while $1 \%$ received help. In terms of communication and training, more help is received. Overall, in the past month, the ratio of help received to help given is $0.66: 1$. For every act of help given, 0.66 is received.

Borrowing and lending in the past six months show the movement of capital or funds in the financial market. The frequency of borrowing and lending is provided in Figure 7. For every case of lending, there are 1.213 cases of borrowing. This zone is a net borrower, as $69.28 \%$ of the respondents did not borrow money and $63.48 \%$ did not lend money the past six months. 


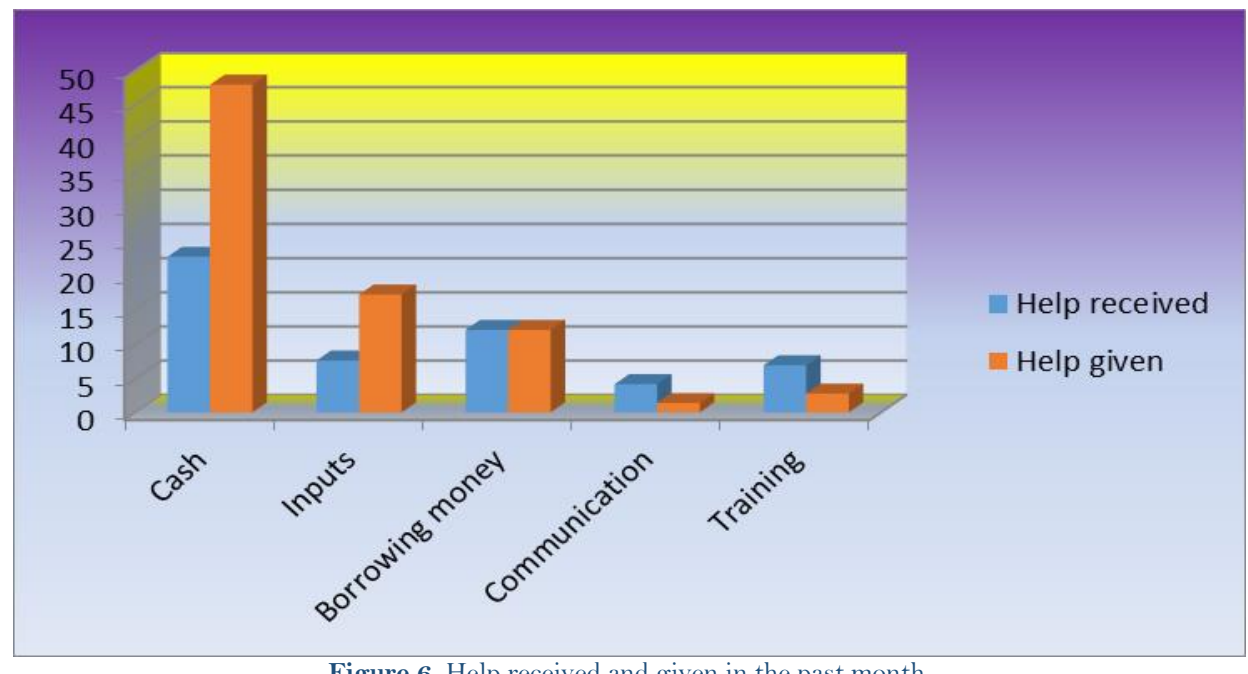

Figure 6. Help received and given in the past month.

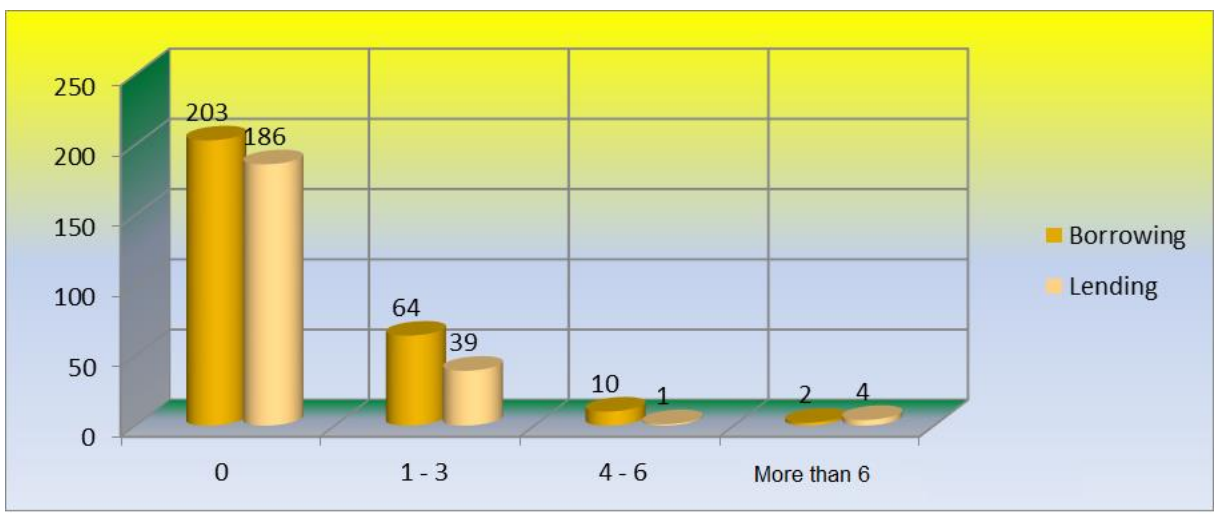

Figure 7. Borrowing and lending (Last six months).

If respondents want money, they will borrow from banks, credit unions, family, friends, and money lenders. Figure 8 provides the respondents' sources of borrowing. Most of the respondents rank their friends as their primary source of borrowing, followed by families and banks. Money lenders and credit unions are the last place they will go to if they need to borrow.

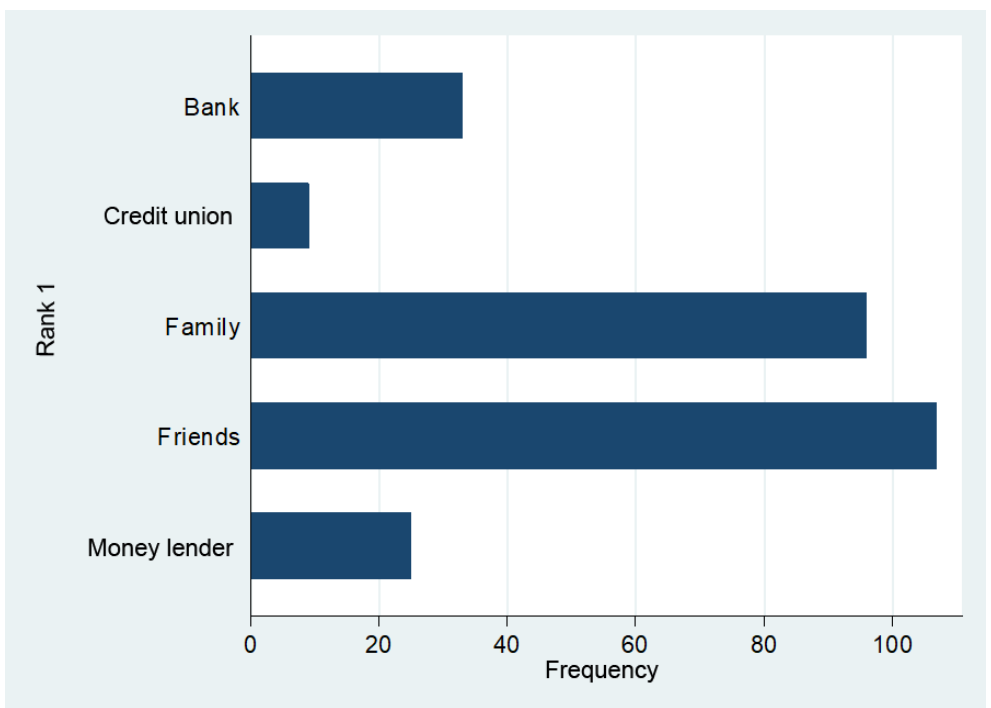

Figure 8. Borrowing money.

Regarding how easy or difficult it is to borrow, most respondents stated that borrowing is difficult or very difficult (54.25\%), and $33.69 \%$ are neutral (see Figure 9). 


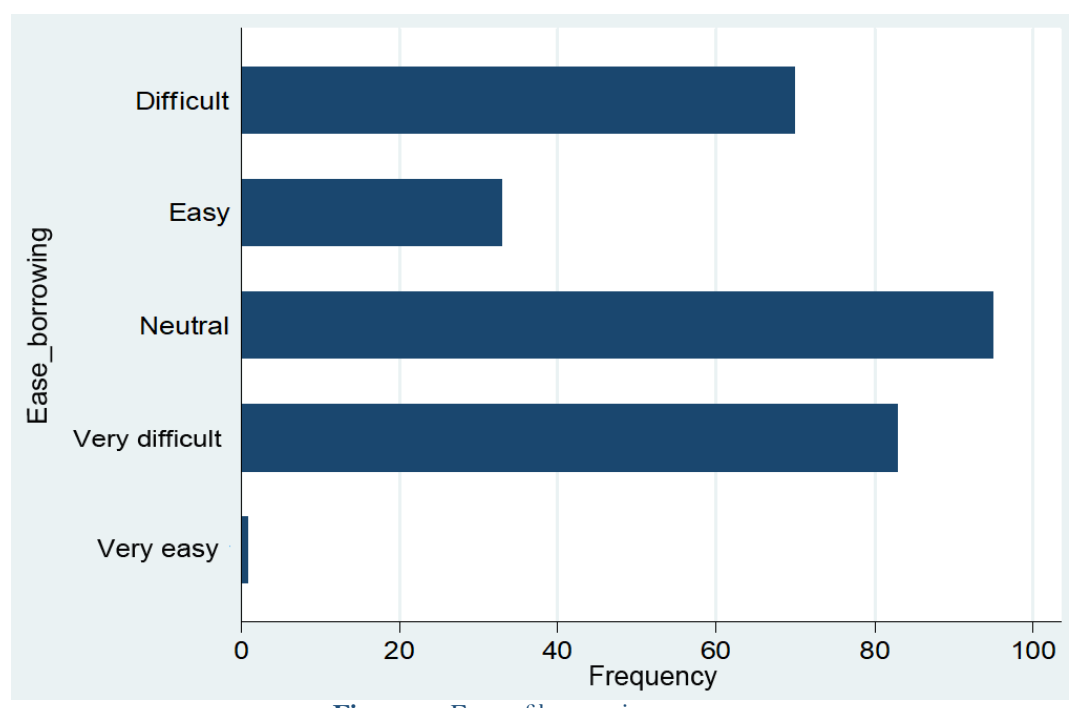

Figure 9. Ease of borrowing money.

\subsection{Sensitivity to Heath, Food, Water and Climate Change}

4.9.1. Access to Healthcare and Sensitivity to Health

In addressing climate change and its effects on respondents' health, access to health facilities is very important (see Table 6). The majority (92.94\%) stated that it takes them less than 40 minutes to get to the nearest facility, $58.82 \%$ stated that it takes them less than 20 minutes, and $6.27 \%$ stated that it takes them at least 40 minutes to get to their nearest health facility.

Regarding access for women, $87.5 \%$ stated that it takes them less than 40 minutes to get to the nearest facility, while the figure for men is $94.84 \%$. In terms of access to health care, the gender gap is evident.

Table 6. Access to health care.

\begin{tabular}{l|c|c|c}
\hline Travel time & Freq. & Percent & Cum. \\
\hline O to less than 20 minutes & 150 & 58.82 & 58.82 \\
\hline 20 to less than 40 minutes & 87 & 34.12 & 92.94 \\
\hline 40 to less than 1 hour & 10 & 3.92 & 96.86 \\
\hline Above 1 hour & 6 & 2.35 & 99.22 \\
\hline Total & 225 & 100.00 & \\
\hline
\end{tabular}

Sensitivity to climate change and health is addressed by looking at illness and work missed over the past 12 months. We look at incidences of malaria, diarrhea, common cold and fever over the last 12 months, and how the respondents' activities were constrained by the lack of cash, water, electricity, and knowledge; the rise in sea level; coastal erosion; flooding; and shortage of labor. We also look at the strategies used to overcome health problems during variable and extreme climate, such as eating healthily, going to hospital, cleanliness, use of herbal medicine, or doing nothing.

Figure 10 depicts the illnesses suffered by respondents in the last 12 months. In the past six months, $44.75 \%$ of the respondents did not get malaria, $66.85 \%$ did not have diarrhea, $38.76 \%$ did not get the common cold, and $59.55 \%$ did not have a fever.

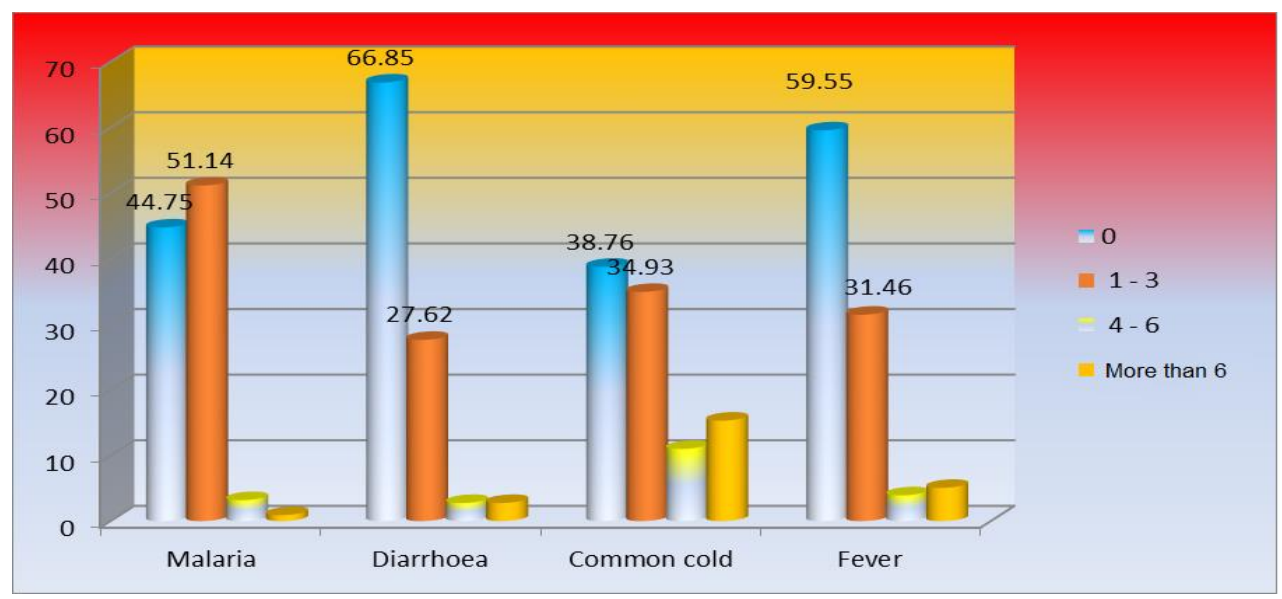

Figure 10. Diseases suffered last 12 months. 
The majority $(89.83 \%)$ of the respondents believed that their activities were constrained by lack of cash, $26.78 \%$ by lack of water, $34.58 \%$ by lack of electricity, $32.2 \%$ by lack of knowledge/techniques, $46.10 \%$ by sea level rise, $25.85 \%$ by coastal erosion, $41.02 \%$ by flooding, and $40 \%$ by shortage of labor. They used adaptation strategies to deal with health problems during variable and extreme climate, such as eating healthily, going to hospital, ensuring cleanliness, using herbal medicine, and doing nothing. Figure 11 provides the adaptation strategies that respondents would use to deal with health problems due to climate change, with $73.9 \%$ stating that they will go to hospital, $1.36 \%$ stated that they will do nothing, and $14.58 \%$ will use herbal medicine.

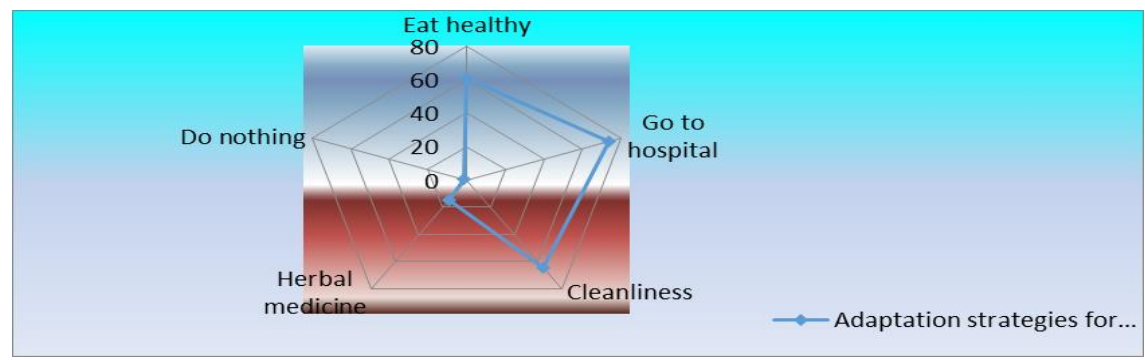

Figure 11. Adaptation strategies for health problems.

\subsubsection{Sensitivity To Food}

Access to food and how climate change will affect that is an important issue to consider. Table 7 provides the information on food shortage and the duration of the shortage. Most respondents stated that they did not experience shortage of food in a year $(85.42 \%)$. The rest experienced shortages of a few months.

\begin{tabular}{l|c|c|c}
\multicolumn{4}{c}{ Table 7. Food shortage. } \\
\hline & Freq. & Percent & Cum. \\
\hline No shortage & 252 & 85.42 & 85.42 \\
\hline 1-2 months & 35 & 11.86 & 97.29 \\
\hline 2-3 months & 7 & 2.37 & 99.66 \\
\hline Longer than 3 months & 1 & 0.34 & 100.00 \\
\hline Total & 295 & 100.00 & \\
\hline
\end{tabular}

Prices of food items have been increasing over time. According to $92.41 \%$ of respondents, the prices of food have increased in the last year, and $86 \%$ stated that prices have increased over the last five years. The main sources of food supplies, according to $98.65 \%$ of the respondents, are from shops and markets, $1.65 \%$ stated that they obtained food in exchange for labor, $0.68 \%$ stated that they mainly borrow from neighbors, and $0.34 \%$ stated that they use remittances.

\subsubsection{Sensitivity to Water}

The main source of drinking water is piped water, with $94.59 \%$ stating that their main source of drinking water is piped water, and the rest use a dug well. The time travelled to get to the nearest facility to fetch water is provided in Table 8 . Most of the respondents (90.88\%) stated that it takes them less than 20 minutes to fetch water. Almost all of them (99.66\%) stated that it takes less than 40 minutes to fetch water. The supply and quality of drinking water during the last 12 months and the last five years have been improving.

Table 8. Time to the nearest facility to fetch water.

\begin{tabular}{l|c|c|c}
\hline Time to get to the nearest facility & Freq. & Percent & Cum. \\
\hline O to less than 20 minutes & 269 & 90.88 & 90.88 \\
\hline 20 to less than 40 minutes & 26 & 8.78 & 99.66 \\
\hline Above 1 hour & 1 & 0.34 & 100.00 \\
\hline Total & 296 & 100.00 & \\
\hline
\end{tabular}

\subsubsection{Sensitivity to Exposure}

A total of $81.01 \%$ of respondents stated that they are aware of climate change. They get information about climate change through newspapers $(4.46 \%)$, the internet $(5.80 \%)$, radio $(61.61 \%)$, television $(59.82 \%)$ and others $(15.11 \%)$, and $63.5 \%$ stated that they employ adaptation strategies to cope with climate change variability, ranging from saving and borrowing money, become involved in other livelihood activities, eat healthily, maintain cleanliness, and use government and NGO assistance to reduce consumption. According to the respondents, the favored adaptation strategy is to save (39.01\%), followed by involvement in other livelihood activities (36.32\%). This is a slight difference between the percentage of respondents who believe that their home can or cannot withstand exposure to wind, coastal erosion, sea level rise and flooding; $44.55 \%$ 
believe that their home can withstand exposure to wind, coastal erosion, sea level rise and flooding, while $46.05 \%$ believe that their homes cannot withstand exposure to these elements.

During the last 12 months, households experienced flooding, drought, sea level rise and coastal erosion due to climate change. A total of $40.30 \%$ of respondents stated that they experienced threats in terms of flooding, and $52.92 \%$ said that they received a warning of such threats. When it comes to coastal erosion, $23.58 \%$ experienced coastal erosion threats, and $36.11 \%$ said that they were warned of such shocks. In terms of drought, $18.83 \%$ stated that they experienced this threat, and $33.34 \%$ admitted receiving a warning of such threats. Regarding sea level rise, 39.67\% stated that they experienced a threat related to sea level rise, and $48.43 \%$ stated that they received a warning of such shocks.

\subsection{Adaptation Scenarios}

The adaptation strategies proposed include doing nothing, getting involved in community activities, asking for financial or government assistance, cleaning the environment, constructing roads and other infrastructure, constructing storage and toilet facilities, installing proper drainage systems, tree planting and protecting coastal areas. Most of the respondents (73.76\%) did not like the idea of doing nothing, with most showing a preference for the other adaptation options mentioned.

\section{Conclusion}

The results show that most of the respondents are household heads, male, married, and educated. Most women interviewed are educated at the primary, secondary, and adult literacy levels. Close to $17 \%$ of the respondents earn above 40,000 Dalasis per year, and most women earn less than D20,000 per annum. The majority of respondents are self-employed as fishermen, fish dryers, fish smokers, ship builders and boat riders. Fishing and fishing-related activities comprise more than half of the respondents' sources of income.

The majority of respondents have access to mobile phones, followed by radio and TV. Sources of capital for coastal dwellers are incomes from fishing, associations, friends, salaries, pensions and credit unions. This is followed by family and osusu. Most of the borrowing is done individually, and the line of credit is mostly below D20,000, and more than $85 \%$ receive less than that amount. More than $60 \%$ of the respondents have no access to land, and $4.71 \%$ stated that they do not have access to water. About $48 \%$ of respondents give cash help, while $22.76 \%$ receive cash help. In terms of borrowing money, $1 \%$ give help, while $1 \%$ receive help. About $70 \%$ of the respondents did not borrow money, and $63.48 \%$ did not lend money during the past six months. Coastal dwellers find it difficult to borrow for investment and consumption. Most of the respondents ranked their friends as their primary source of borrowing, followed by families and banks. Access to health facilities is a major challenge for coastal inhabitants. About $93 \%$ stated that it takes them less than 40 minutes to get to the nearest health facility. In the last 12 months, more than $38 \%$ of the respondents suffered from malaria, diarrhea, the common cold, or fever. Activities were constrained by lack of cash, water, electricity, sea level rise, coastal erosion, flooding and shortage of labor. Awareness of climate change is very high among respondents, with more than $81 \%$ claiming awareness of climate change and stating that they get information about climate change variability through newspapers, internet, radio and television. Radio is ranked highest followed by TV. Adaptation strategies employed to deal with health problems during variable and extreme climate are going to hospital, cleanliness, eating healthily, and using herbal medicine. More than $85 \%$ of the respondents did not experience a shortage of food in a year, but the price of food has been increasing over the last five years. More than $94 \%$ of respondents use piped water as their main source of drinking water and the rest use a dug well. According to the respondents, the favored adaptation strategy is to save, followed by other livelihood activities. The adaptation strategies proposed include doing nothing, community involvement, financial assistance, government assistance, cleaning the environment, construction of roads and other infrastructure, storage and toilet facilities, proper drainage systems, tree planting, and protection of coastal areas.

\section{References}

Acquah, H. D.-G. (2011). Farmers perception and adaptation to climate change: A willingness to pay analysis. Journal of Sustainable Development in Africa, 13(5), 150-161.

Adams, R. M., Rosenzweig, C., Peart, R. M., Ritchie, J. T., McCarl, B. A., Glyer, J. D., \& Allen, L. H. (1990). Global climate change and US agriculture. Nature, 345(6272), $219-224$

Alig, R. J., Adams, D. M., Joyce, L., \& Sohngen, B. (2004). Climate change impacts and adaptation in forestry: Responses by trees and markets. Choices, 19(316-2016-6903), 7-12.

Aphunu, A., \& Nwabeze, G. (2012). Fish farmers' perception of climate change impact on fish production in Delta State, Nigeria. Journal of Agricultural Extension, 6(2), 1-13.

Ayanwuyi, S., Kuponiyi, E., Ogunlade, F., \& Oyetoro, J. (2010). Farmers perception of impact of climate changes on food crop production in Ogbomosho Agricultural Zone of Oyo State, Nigeria. Global Journal of Human Social Science, 10(7), 33-39.

Combest-Friedman, C., Christie, P., \& Miles, E. (2012). Household perceptions of coastal hazards and climate change in the Central Philippines. Journal of Environmental Management, 112, 137-148. https://doi.org/10.1016/j.jenvman.2012.06.018 
Devkota, R. P., Bajracharya, B., Maraseni, T. N., Cockfield, G., \& Upadhyay, B. P. (2011). The perception of Nepal's Tharu community in regard to climate change and its impacts on their livelihoods. International Journal of Environmental Studies, 68(6), 937-946.

Elliott, G. P., \& Baker, W. L. (2004). Quaking aspen (Populus tremuloides Michx.) at treeline: A century of change in the San Juan Mountains, Colorado, USA. Journal of Biogeography, 31(5), 733-745. https://doi.org/10.1111/j.13652699.2004.01064.x

Feng, S., \& Hu, Q. (2007). Changes in winter snowfall/precipitation ratio in the contiguous United States. Journal of Geophysical Research, $112(\mathrm{D} 15), \mathrm{D} 15109$.

Gan, J. (2004). Risk and damage of Southern pine beetle outbreaks under global climate change. Forest Ecology and Management, 191(1-3), 61-71. https://doi.org/10.1016/j.foreco.2003.11.001

Haque, M. A., Yamamoto, S. S., Malik, A. A., \& Sauerborn, R. (2012). Households' perception of climate change and human health risks: A community perspective. Environmental Health, 11(1), 1-12.

IPCC. (2007). Climate change: Impacts, adaptation, and vulnerability. In: Parry ML, Canziani oF, Palutikof JP (eds) Contribution of working group II to the fourth assessment report of the Intergovernmental Panel on Climate Change (pp. 1-131). Cambridge: Cambridge University Press.

Karl, T., Melillo, J., \& Peterson, T. (2009). Global climate change impacts in the United States. Cambridge: Cambridge University Press.

Milly, P., Betancourt, J., \& Falkenmark, M. (2008). Stationarity is dead: Whither water management? Science, 319(5863), $573-574$.

Orindi, V. A., \& Murray, L. A. (2005). Adapting to climate change in East Africa: A strategic approach (No. 117). International Institute.

Scott, M. J., \& Huang, Y. J. (2007). Effects of climate change on energy use in the United States. In: Wilbanks TJ, Bhatt V, Bilello DE et al (eds) Effects of climate change on energy production and use in the United States. Synthesis and Assessment Product 4.5 (pp. 8-44). Washington: U.S. Climate Change Science Program.

Smith, P., Martino, D., \& Cai, Z. (2007). Agriculture. In: Metz B, Davidson OR, Bosch PR et al (Eds.), Climate Change 2007: Mitigation. Contribution of Working Group III to the Fourth Assessment Report of the Intergovernmental Panel on Climate Change. Cambridge University Press, Cambridge.

Sohngen, B., \& Sedjo, R. (2005). Impacts of climate change on forest product markets: Implications for North American producers. The Forestry Chronicle, 81(5), 669-674. https://doi.org/10.5558/tfc81669-5

Tambo, J. A., \& Abdoulaye, T. (2013). Smallholder farmers' perceptions of and adaptations to climate change in the Nigerian savanna. Regional Environmental Change, 13(2), 375-388.

U.S. Environmental Protection Agency (EPA). (2008). Effects of climate change for aquatic invasive species and implications for management and research. National Center for Environmental Assessment, Washington, DC; EPA/600/R-08/014. Available from the National Technical Information Service, Springfield, VA. Retrieved from http://www.epa.gov/ncea.

World Bank. (2007). The Gambia overview: Development news, research, data | World Bank, World. Retrieved from: accessible@www.worldbank.org/en/country/gambia/overview\#1. 